\title{
Urban water sustainability in Australian cities: using the National Water Account to indicate the resilience in water systems
}

\author{
Sunil Dutta, Rob Braaten, Ulrike Bende-Michl and Wijedasa Alankarage \\ National Water Account Unit, Bureau of Meteorology \\ Email: sunil.dutta@bom.gov.au
}

\begin{abstract}
Securing water in Australia is particularly challenging in the context of the country's high natural hydro-climatic variability, population growth and implications from emerging changes of climate pattern. To make informed decisions about Australia's future water security, sound and independent information is needed about the balance of supply and demand across the country.
\end{abstract}

Under the Water Act 2007, the Bureau of Meteorology (the Bureau) was legislated to provide standardised water information across the country; information that previously was not readily available to the public in Australia. The Bureau's annual National Water Account, with its first publication in 2010, provides water resource management information across ten regions in an independent, accountable and reliable form. The accounts are built through close partnership with reporting partners from a wide range of organisations in each State and Territory, as well as other Australian Government agencies, to gather the best available water related physical and regulatory data.

This paper discloses information on urban water availability, allocation and use in six major cities in Australia from the National Water Account perspective and emphasises the balance between water supply and demand over the past six financial years (2010-11 to 2015-16; 1 July to 30 June). Past accounts have shown that total water use in urban centres has steadily increased at the rate of 2-3 per cent annually. Water security across Australia relies mostly on surface water, particularly for the Canberra, Sydney, Melbourne and South East Queensland regions. In Perth, groundwater and desalinated water supply are now the major sources of water due to low surface water availability. In Adelaide and Melbourne, water supply through inter-regional transfers assist in mitigating poor storage inflows.

Using data from the National Water Account, in an analogy to financial indicators, we have developed a number of indicators for water systems under the themes of sustainability and liquidity. This paper presents these indicators for the six urban centres, and shows how the indicators can be useful for a comparison of water supply stress, flexibility, security and resilience between regions as well as for highlighting emerging issues, prioritising and targeting resources.

Keywords: National Water Account, water resilience, sustainability indicators, water availability, water use 
Water sustainability refers to whether the foreseeable future demand can be met in a sustainable way without compromising the ability to meet future water needs. This is often crucial for urban centres where water demand can be influenced by rapid population growth, competing demands for water sources, climate change or pollution influencing water availability as well as source depletion by over-exploitation.

Securing water resources and making informed decisions on future developments require sound monitoring and evaluation of urban water systems, their source availability and security as well as the governance around this process. In water systems, indicators can be useful for these purposes by tracking progress and trends, identifying emerging issues, comparing between regions, and priority setting.

Based on data from the Bureau of Meteorology's National Water Account, this paper presents the use of selected indicators to evaluate the water sustainability in six of Australia's urban major populated centres Adelaide, Canberra, Melbourne, Perth, South East Queensland and Sydney (Figure 1). The National Water Account applies a financial accounting model to water reporting (WASB 2012). Further information can be obtained here: http://www.bom.gov.au/water/nwa. In an analogy to financial indicators, we have developed a number of indicators for accounting regions under the themes of sustainability and liquidity. Through the use of this indicator approach, we aim to extract new insights from the National Water Account dataset, with the objectives to (i) report on the status and trend of water sustainability, (ii) identify regional water supply stress, flexibility, security and resilience between regions and (iii) highlight and analyse emerging issues in water sustainability across the six largest urban water systems across Australia.

\section{METHODS}

Indicators are often used to represent and simplify complex information to inform the public and decision-makers. The financial industry has a long history of using indicators, ratios and metrics to provide insight into corporate health for shareholders and investors (e.g. Penman 2007; Delen et al. 2013). Likewise, the water discipline also has a growing interest in the use of indicators to measure the health of water systems (e.g. $\mathrm{Xu}$ and $\mathrm{Wu}$ 2017; Shilling et al. 2013).

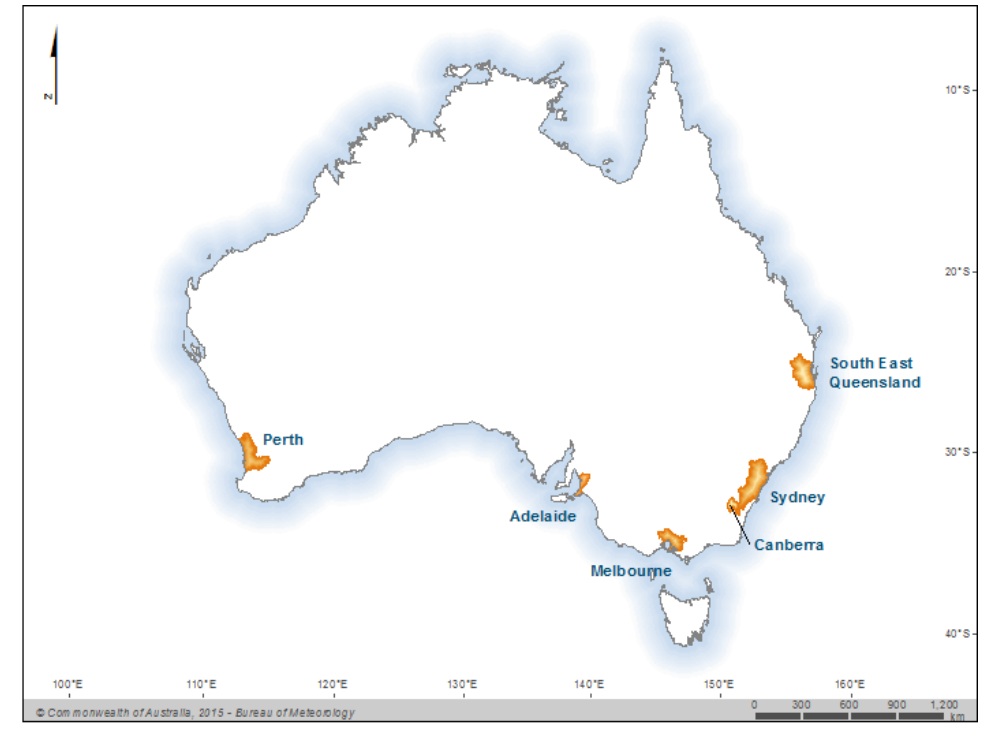

Figure 1. National Water Account regions.

Building on previous work on financial indicator applications to water systems in the early stages of the National Water Account (Hanley and Robinson 2011), and now with the added benefit of six years of water account data covering most of Australia's water use, we evaluated the usefulness of a wide selection of financial metrics and indicators for water reporting.

Financial indicators are generally categorised into key themes relating to business health including: dividend/earnings sustainability; liquidity; leverage; growth; profitability; and asset utilisation. In this paper we investigated the first two themes, sustainability and liquidity, as they had the closest analogies to water system health.

Several examples of these indicators are presented below for the six National Water Account urban water regions. These indicators and their calculation methods are listed in Table 1 and summarised below.

\subsection{Sustainability Indicators}

Sustainability indicators in the financial field generally represent the amount of revenue or earnings paid out (to shareholders, debt holders, etc.) relative to the amount retained in the business and reinvested to ensure longterm business sustainability. Examples include the dividend payout ratio, dividend cover ratio, operating surplus ratio and debt service ratios. 
Table 1. Indicators and calculation methods

\begin{tabular}{|c|c|c|c|}
\hline Type & Indicator & Numerator & Denominator \\
\hline \multirow[t]{3}{*}{$\begin{array}{l}\text { Sustainability } \\
\text { indicators }\end{array}$} & Water use index & Total usage & $\begin{array}{l}\text { Total inflows minus wastewater } \\
\text { inflows } 1\end{array}$ \\
\hline & $\begin{array}{l}\text { Water use index } \\
\text { (groundwater) }\end{array}$ & Groundwater extractions & Groundwater inflows \\
\hline & $\begin{array}{l}\text { Water use index } \\
\text { (surface water) }\end{array}$ & Surface water diversions & $\begin{array}{l}\text { Surface water inflows minus inter- } \\
\text { region surface water deliveries }\end{array}$ \\
\hline \multirow[t]{5}{*}{$\begin{array}{l}\text { Liquidity/ } \\
\text { security } \\
\text { indicators }\end{array}$} & $\begin{array}{l}\text { Total water liquidity } \\
\text { ratio }\end{array}$ & $\begin{array}{l}\text { Water assets }{ }^{3}+\text { estimated net storage } \\
\text { inflows }+ \text { net aquifer recharge from }^{4} \\
\text { landscape }{ }^{4} \text { - estimated releases }+ \\
\text { estimated inter-region deliveries (to } \\
\text { region) }+ \text { desalination capacity }{ }^{5}+ \\
\text { recycled water use }\end{array}$ & $\begin{array}{l}\text { Water liabilities + groundwater } \\
\text { entitlements + surface water } \\
\text { entitlements }\end{array}$ \\
\hline & $\begin{array}{l}\text { Water asset liquidity } \\
\text { ratio }\end{array}$ & $\begin{array}{l}\text { Water assets }{ }^{3} \text { (including inter-region } \\
\text { claims) }\end{array}$ & $\begin{array}{l}\text { Water liabilities + groundwater } \\
\text { entitlements }+ \text { surface water } \\
\text { entitlements }\end{array}$ \\
\hline & $\begin{array}{l}\text { Water inflow liquidity } \\
\text { ratio }\end{array}$ & $\begin{array}{l}\text { Estimated net storage inflows - estimated } \\
\text { environmental releases }+ \text { net aquifer } \\
\text { recharge from landscape }\end{array}$ & $\begin{array}{l}\text { Water liabilities + groundwater } \\
\text { entitlements + surface water } \\
\text { entitlements }\end{array}$ \\
\hline & $\begin{array}{l}\text { Climate independent } \\
\text { water liquidity ratio }\end{array}$ & $\begin{array}{l}\text { Desalination capacity }{ }^{5}+\text { Recycled water } \\
\text { use }^{6}\end{array}$ & $\begin{array}{l}\text { Water liabilities }+ \text { groundwater } \\
\text { entitlements }+ \text { surface water } \\
\text { entitlements }\end{array}$ \\
\hline & $\begin{array}{l}\text { Inter-region water } \\
\text { liquidity ratio }\end{array}$ & $\begin{array}{l}\text { Estimated inter-region deliveries (to } \\
\text { region) }\end{array}$ & $\begin{array}{l}\text { Water liabilities }+ \text { groundwater } \\
\text { entitlements }+ \text { surface water } \\
\text { entitlements }\end{array}$ \\
\hline \multicolumn{4}{|c|}{$\begin{array}{l}{ }^{1} \text { Total inflows include all natural inflows where available. Wastewater was removed from inflows to avoid double-counting of natural } \\
\text { inflows }\end{array}$} \\
\hline \multicolumn{4}{|c|}{${ }^{2}$ Inter-region flow was removed to reflect only natural surface water inflows } \\
\hline \multirow{2}{*}{\multicolumn{4}{|c|}{$\begin{array}{l}{ }^{3} \text { Groundwater asset information was available only for Adelaide, Melbourne and South-East Queens } \\
{ }^{4} \text { Information was available only for Perth } \\
{ }^{5} \text { Desalination capacity was derived from Bureau of Meteorology's Climate Resilient Water Sources } \\
{ }^{6} \text { Recycled water use for } 2015-16 \text { year was taken as a proxy of recycled water use }\end{array}$}} \\
\hline & & & \\
\hline \multicolumn{4}{|c|}{$\begin{array}{l}\text { Analogous water indicators include variations of 'exploitation' or 'stress' indices which have been used } \\
\text { previously in the water field (WaterinCore 2010; Shilling et al. 2013). These represent the proportion of overall } \\
\text { water availability in a water system that is committed to consumptive use. The remaining uncommitted or } \\
\text { unused water is the volume left in the system for environmental benefit, future water supply flexibility and } \\
\text { resilience and, in some cases, flood mitigation. }\end{array}$} \\
\hline
\end{tabular}

Several examples of these usage indicators were calculated based on National Water Account data (Table 1), and are referred to in this paper as 'water use indices' that are synonymous to water exploitation index (WaterinCore 2010) or water stress index (California Department of Water Resources 2014). These refer to actual usage as a proportion of water availability and could be considered analogous to the dividend payout ratio.

In principle environmental water could be also referred to as water use for some river systems of Australia, with water being delivered via licensed environmental entitlements. However, these are not generally a feature of the urban National Water Account regions and hence are not included in this analysis. However in future, if the indicator approach were to be applied to the regions such as Murray-Darling Basin, licensed environmental water could perhaps be represented with another indicator.

\subsection{Liquidity Indicators}

Liquidity indicators in the financial industry generally represent the amount of cash or liquid assets available to an organisation relative to its current liabilities. These indicators include the current ratio or quick ratio (measures of available assets relative to liabilities) or operating cash flow ratio (measure of cash flow from operations relative to liabilities).

In the water field, an analogous concept is water security, which represents the capability of a water system to reliably meet human needs from its available 'liquid' water resources. These could include available water assets (e.g. water in storage, inter-region claims), projected net inflows, or alternative supply capacity such as desalination. The concept of water security has been used by, for example, Seqwater in its 'water security gauge' (Seqwater 2014) as well as in the international development field (e.g. Global Water Partnership 2014). 
A number of example water liquidity or security indicators have been calculated for the urban National Water Account regions, as outlined in Table 1. The total liquidity ratio represents the total estimated 'liquid' water supply capacity for the coming financial year divided by the commitments for human use. The other ratios are subcomponents of the total liquidity index, representing the contribution of assets, inflows, climate independent sources, and inter-regional deliveries to water liquidity. In financial terms, the asset liquidity ratio is analogous to the 'current ratio' in financial analysis; while the inflow liquidity ratio is analogous to the 'operating cash flow ratio'.

To provide insight into water sustainability in urban systems across Australia the following available data were used from the National Water Accounts 2010-16 to calculate selected sustainability and liquidity indicators:

- total water inflows including surface and groundwater,

- surface water, groundwater, desalinated water and inter-region water usages,

- water entitlements, surface water and groundwater allocations and water liabilities,

- water assets, desalinated water capacity, recycled water use, future net storage inflows for the following financial year, groundwater recharge, and inter-region deliveries.

\section{RESULTS AND DISCUSSION}

The water use index for the six urban regions of the National Water Account is shown in Figure for the past six years. The water use index fluctuates from year to year, mainly reflecting the effects of climate variability. During drier years, the index tends to increase due to the combined effects of reduced inflows of streamflow and increased urban usage.

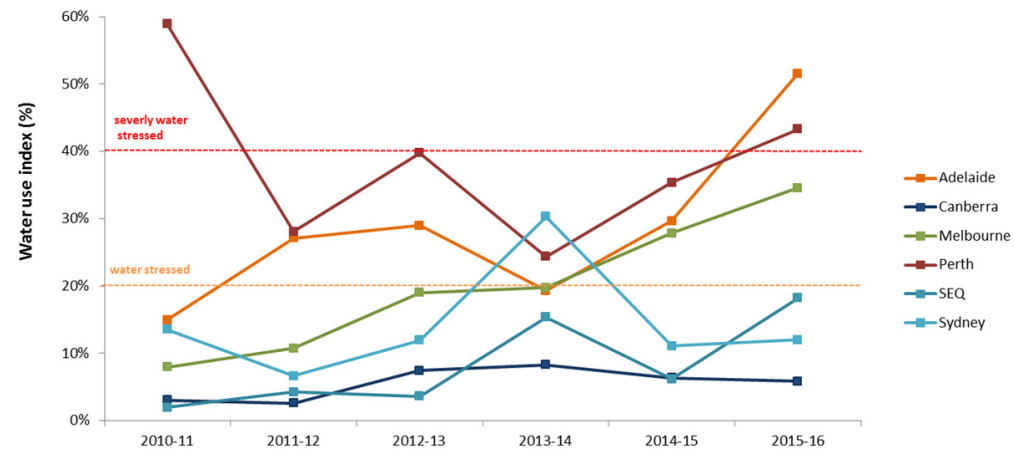

Figure 2. Water use index for the six National Water Account urban regions.

Water use index thresholds of $20 \%$ and $40 \%$ (Figure ) have previously been used to indicate the potential for "water stressed" and "severely water stressed" regions (European Environment Agency 2004, WaterinCore 2010). Based on these thresholds, the index consistently shows low water stress values for Canberra, South East Queensland and Sydney regions. The index indicates severe water stress in both Adelaide and Perth regions in 2015-16 as well as for two earlier years in Perth. The index for Perth in 2010-11 is unusually high as the region experienced particularly low rainfall resulting in record low inflows to storages in that year. The other regions remained below the 20\% threshold for the six year period of record, except for one dry year in Sydney (2014).

Melbourne and Adelaide have experienced increasing trends in their water use indices from less than $20 \%$ in 2010-11 to greater than $30 \%$ in 2015-16, related mainly to declining rainfall that resulted in reduced groundwater and surface water inflows over this period.

However, the authors acknowledge that the trends in water use index values might also be influenced by changes in estimation methods of the two input variables over time: runoff to reservoirs and rivers; as well as groundwater recharge from landscape. The Australian Water Resource Assessment-Landscape (AWRA-L) model version 5.0 (Viney et al. 2015) was used to estimate runoff to reservoirs and rivers for the 2015-16 year. Earlier versions of this model were used to estimate runoff to reservoirs and rivers in previous years except for Perth, where the GR4J model (Perrin et al. 2003) was used. Groundwater recharge from the landscape was estimated in 2015-16 using the AWRA-L model, and in earlier years using the Water Atmosphere Vegetation Energy and Solutes (WAVES) model (Zhang and Dawes 1998), except in Perth where the local PRAMS and PHRAMS models were used for all years (Government of Western Australia Department of Water 2009; URS 2009). 
The three regions with the highest water use index values, Perth, Adelaide and Melbourne, all rely increasingly on water sources that are not related to natural inflows in the region. To secure its water demand, Perth has increased the use of desalination (47\% of total urban supply in 2015-16) and has initiated a groundwater replenishment (managed aquifer recharge) scheme, while Adelaide and Melbourne both have increased interregional deliveries (137 GL and 249 GL in 2015-16, respectively). These alternative water supplies, which are taken into consideration in the calculation of the water use index, have contributed to higher index values. Water supply from the Thomson Reservoir to Melbourne has been treated as inter-region transfers in the National Water Account. Thomson Reservoir is physically located beyond the region and also serves other external users.

Figure 3 shows a subset of the information in Figure 2, comparing the groundwater and surface water use indices between regions for the 2015-16 year. It shows the increasing reliance on alternative water sources in Perth, Adelaide and Melbourne also reflects the higher abstraction of the natural water resources (surface and groundwater) in these regions. The high water use index in Perth and Adelaide is manifested to a greater extent in groundwater extraction than surface water diversions. Both cities show an index value above the $40 \%$ threshold denoting potential "severe stress" for groundwater. This is also reflected in falling groundwater levels and an increasing focus on managed aquifer recharge in both cities (e.g. see http://www.bom.gov.au/water/groundwater/insight/).

No groundwater use index values are available for Canberra, SEQ and Sydney as groundwater inflows are not quantified in the National Water Account for these areas. However groundwater usage in these regions is very small relative to surface water.

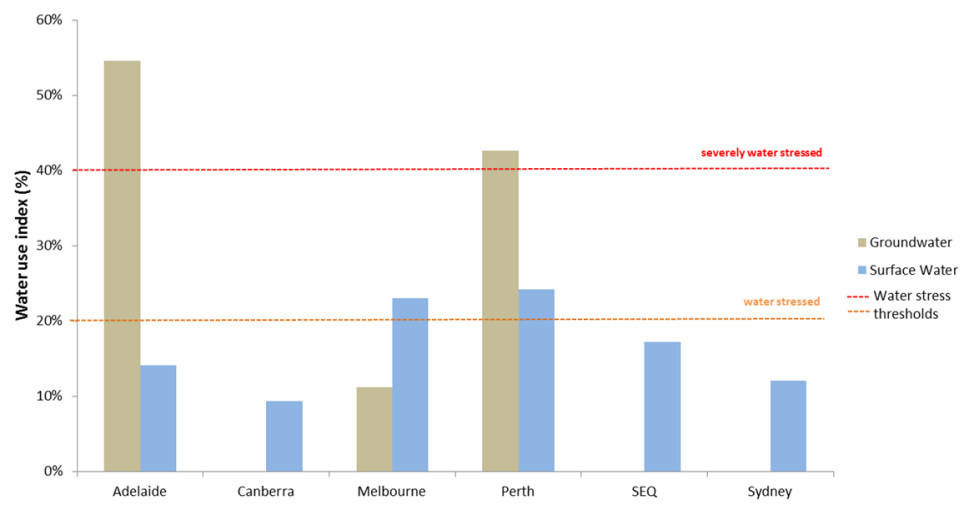

Figure 3. Water use index of groundwater and surface water in 2015-16 across the six urban National Water Account regions (note: groundwater index was not calculated for Canberra, SEQ and Sydney).

While the water use index reflects past conditions, the total water liquidity index is forward looking, providing an indication of resilience and security for the future year's water supply. This is based on the water assets of a region relative to its future year's water liability and commitment, and thus how many years of water demand could be met. Figure 4 shows the total water liquidity index as well as the liquidity subindices for each of the urban areas as of end of June 2016.

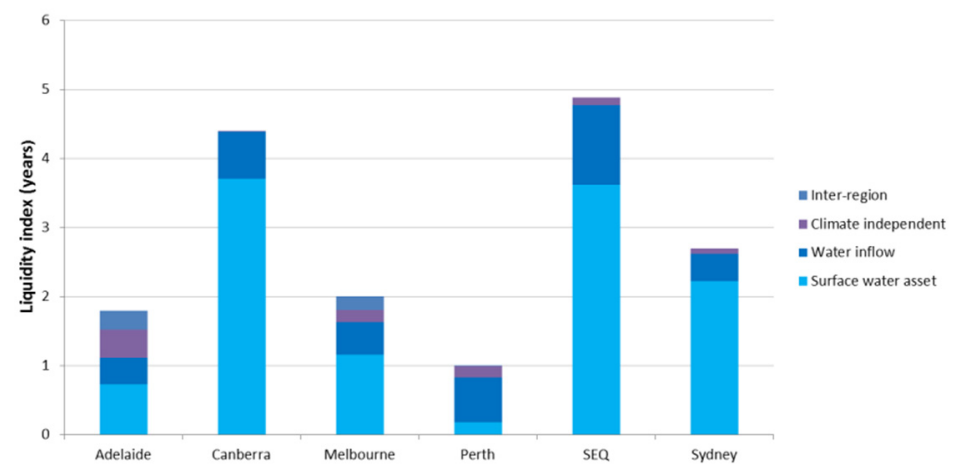

Figure 4. Total water liquidity index and subindices at 30 June 2016 for the National Water Account urban regions. 
Overall the index values for 2016 show a higher level of water liquidity for future supply in the three eastern urban regions of Canberra, South East Queensland and Sydney, indicating a higher level of water resilience in these areas. This is mainly provided by substantial storage in each of these three regions, representing several years' worth of banked surface water supply. This index would be even higher if groundwater assets could be recognised for Canberra and Sydney. Groundwater assets were recognised for the calculation of the index for Adelaide, Melbourne and South-East Queensland only.

The high liquidity value in South East Queensland likely reflects the benefits that are now derived from investment in water supply infrastructure in addition to sufficient rainfall years that have filled storages in this region following the severe effects of the Millennium Drought in the early part of the 2000s.

Melbourne and Adelaide have moderate level of liquidity, comprising a mix of stored water, projected inflows, plus significant capacity for climate independent supplies and inter-region transfers. Both have significant climate independent liquidity due to past investments in desalination following the Millennium Drought, providing added resilience to climate variability and change. Based on this indicator both cities would have sufficient water to meet about two years' of water demand. In addition, given Adelaide's significant use of groundwater, if projected groundwater recharge were to be included, its liquidity index would be even higher. (Currently projected groundwater inflows are only estimated in the Perth region.)

Compared to all of the urban regions, Perth shows the lowest liquidity, with available capacity very close to the anticipated supply requirements. However, Perth relies largely on groundwater; and the groundwater asset was not recognised due to data unavailability. Therefore, the liquidity index is likely to be underestimated for Perth. With lower volumes of water banked in surface water storages, reflecting continued low rainfall and dam inflows over the past decades, the region is highly dependent on projected inflows for the next year. These inflows are primarily made up of anticipated groundwater recharge.

\section{CONCLUSIONS}

The sustainability and liquidity indicators are useful for a comparison of water supply, flexibility, security and resilience between regions as well as for highlighting emerging issues, prioritising and targeting resources. Examples from the results presented above highlighted the status of water resource systems across the six major urban regions across Australia; including that there is a (i) upward trajectory in Adelaide and Melbourne's water exploitation levels, (ii) an increasing risk of groundwater stress in both Adelaide and Perth as well as (iii) a declining level of water liquidity in Perth.

The indicators can be useful in governing decisions and actions taken by water utilities and State regulators as well as contributing to community education regarding the reasons for these decisions. Examples where the chosen indicator results could provide support for past decisions and actions include the demonstration of the (i) liquidity benefits of recent investment in climate-independent water supply capacity in Melbourne, Adelaide and Perth; and (ii) water security benefits provided by infrastructure upgrades in Southeast Queensland following the Millennium Drought.

In terms of prioritisation, the indicator analysis highlights that the highest priority region for further investment in water supply infrastructure is likely to be Perth due to its relatively low liquidity index compared with the other urban regions. However, this study also demonstrates the uncertainty around estimating some of the water sources, such as groundwater assets which are likely to influence some of the indicators.

Although trialled here for the urban regions, in future these indicators could be applied to other regions throughout Australia, including the Murray-Darling Basin, to provide a more extensive overview of emerging water issues, status and trends across the country. This work could be also complemented by selecting additional indicators that are linked to other types of water sustainability goals and associated objectives applicable to environmental flows, cultural and social benefits.

\section{ACKNOWLEDGEMENT}

This paper was prepared based on water information published in the National Water Accounts $2010-11$ to 2015-16. The National Water Account is the result of close collaboration between the Bureau and Australian, State, Territory, and Local government agencies, water service providers, and other organisations. The authors acknowledge the support of all those reporting partners who have contributed to the preparation of Bureau's annual National Water Accounts. We also like to thank the reviewers who helped to improve the quality of the paper. 
Dutta et al., Urban water sustainability in Australian cities

\section{REFERENCES:}

California Department of Water. 2014. The California water sustainability indicators framework.

http://www.water.ca.gov/waterplan/docs/cwpu2013/Final/vol4/sustainability/05Sustainability_Indicators_Frame work.pdf

Delen, D., Kuzey, C., and Uyar, A. 2013. Measuring firm performance using financial ratios: A decision tree approach. Expert Systems with Applications: 40(10): 3970-3983.

European Environment Agency 2004. Water exploitation index. https://www.eea.europa.eu/data-andmaps/indicators/water-exploitation-index-1

Global Water Partnership. 2014. Proceedings from the GWP workshop: Assessing water security with appropriate indicators.

http://www.gwp.org/globalassets/global/toolbox/publications/p763_gwp_proceedings_paper.pdf

Government of Western Australia Department of Water. 2009. Perth Regional Aquifer Modelling System (PRAMS) model development: calibration of the coupled Perth Regional Aquifer Model PRAMS 3.0. https://www.water.wa.gov.au/_data/assets/pdf_file/0017/5480/90781.pdf

Hanley, S. and Robinson, S. 2011. Applying General Purpose Water Accounting Reports. http://www.bom.gov.au/water/standards/wasb/documents/analysing_gpwa_reports.pdf

Penman, S. 2007. Financial Statement Analysis and Security Valuation. McGraw-Hill/Irwin.

Perrin, C., Michel, C. and Andreassian, V. 2003. Improvement of a parsimonious model for streamflow simulation. Journal of Hydrology, vol 279: 275-289 pp.

Seqwater. 2014. Water Outlook for South East Queensland. http://www.logan.qld.gov.au/_data/assets/pdf_file/0003/351480/2014-Water-Outlook-FINAL.pdf

Shilling, F., Khan, A., Juricich, R, and Fong, V. 2013. Using Indicators to Measure Water Resources Sustainability in California. World Environmental and Water Resources Congress.

URS, 2009. Peel-Harvey Coastal Groundwater Model WA - Model Construction and Calibration, prepared for CSIRO, Australia.

Viney, N.,Vaze, J., Crosbie, R., Wang, B., Dawes, W. and Frost, A. 2015, AWRA-L v5.0: Technical description of model algorithms and inputs, CSIRO, Canberra

Water Accounting Standards Board. 2012. Australian Water Accounting Standard 1. Preparation and Presentation of General Purpose Water Accounting Reports. Bureau of Meteorology.

WaterinCore. 2010. Sustainable Water Management through Common Responsibility Enhancement in Mediterranean River Basins. Water Management. Common List of Indicators \& Database.

http://www.waterincore.eu/deliverables/03 03 01 en.pdf

Xu, H. and Wu. M. 2017. Water Availability Indices - A Literature Review. Argonne National Laboratory, Energy Systems Division.

http://water.es.anl.gov/documents/Technical\%20Report_\%20Literature\%20Review\%20of\%20Water\%20Availa bility\%20Indices_030317.ems_vs.pdf

Zhang, L. and Dawes, W.R. 1998. WAVES - An integrated energy and water balance model. CSIRO Land and Water Technical Report No. 31/98. 